\title{
Survey for the Assessment of Stem Rot of Capsicum Incidence in Southern Karnataka
}

\author{
B. Sahana ${ }^{1}$, T. B. Manjunatha Reddy ${ }^{2 *}$, B. Doddabasappa ${ }^{3}$, \\ B. Anjaneya Reddy ${ }^{4}$,S. K. Mushrif ${ }^{2}$ and H. Amarananjundeswara ${ }^{5}$ \\ ${ }^{1}$ Department of Plant Pathology, College of Horticulture, Bengaluru, Karnataka, India \\ ${ }^{2}$ Department of Plant Pathology, ${ }^{3}$ Department of Entomology, College of Horticulture, \\ Kolar, Karnataka, India \\ ${ }^{4}$ Horticultural Research and Extension Centre, Hogalagere, Kolar, Karnataka, India \\ ${ }^{5}$ Horticultural Research and Extension Centre, Somanhalli Kaval, Hassan, Karnataka, India \\ *Corresponding author
}

\section{A B S T R A C T}

\section{Keywords \\ Survey, Stem rot, Disease incidence, Capsicum}

\section{Article Info}

Accepted:

10 August 2020

Available Online:

10 September 2020

\begin{abstract}
Diseases of capsicum act as the major limiting factors to its economic production. Recently, the stem rot caused by Sclerotium rolfsii Sacc. is becoming severe disease of capsicum in India. Hence, to get a preliminary idea regarding the incidence level and pattern of prevalence of the disease in Southern region of Karnataka, a roving survey was conducted during the cropping seasons in the major capsicum growing areas of Bengaluru rural, Chikkaballapur and Kolar districts during kharif and rabi 2018-2019. The disease incidence ranged from 0.00 to 06.00 per cent in both open and protected conditions. Among the three districts surveyed, Harati village in Kolar district showed maximum disease incidence of 06.00 per cent in the hybrid Indra. As observed in survey, the crop was prone to the disease at the seedling and flowering stage along with the availability of large amount of moisture.
\end{abstract}

\section{Introduction}

Capsicum (Capsicum annuum var. grossum Sendt.) is grown in almost every part of India. It is commercially cultivated in Andhra Pradesh, Karnataka, Punjab, Bihar and Maharashtra. The farmers in Bengaluru rural, Chikkaballapur and Kolar districts of Karnataka are taking up the capsicum cultivation in both open and protected conditions, since good economic returns are being realized. The cultivation under poly house conditions has created awareness poly house cultivation offers several advantages like production risk is comparatively less than open field condition, 10-12 times higher yield than that of outdoor cultivation, proper nourishment of the crop, opportunity for year round production, efficient utilization of land and resources. This economic return can increase manifolds if capsicum is selected for cultivation in poly houses. The productivity during off-season can be increased many fold through poly house cultivation technologies 
by growing capsicum throughout the year. Thus the poly house cultivation of capsicum creates a favourable environment for the sustained growth of crop so as to realize its maximum potential even in adverse climatic conditions.

However, the capsicum crop is prone to several diseases viz., anthracnose, cercospora, charcoal rot, damping off, root rot, downy mildew, fusarium wilt, powdery mildew, stem rot and verticilium wilt etc. Among these stem rot caused by a soil borne pathogen Sclerotium rolfsii Sacc. is the emerging disease, causing major crop loss. Stem rot is an important soil borne disease with more than 500 plant species including vegetable, ornamental, pulse, oilseed and medicinal crops are attacked by this pathogen (Farr et al., 1989). The stem rot disease on solanaceous crop may occur at any growth stage of the plant (Begum et al., 1985). The stem rot affected plant shows invasion of the fungus, in the form of a girdle in the collar region, just above the soil line.

The girdling progresses upwards, along with the white mycelium. Later on, cream to chocolate coloured sclerotia will be formed. Wilting occurs within 3-5 days and the entire plant dries up with the abolition of the green canopy. The dried leaves remain intact with the stem with poor root growth. Rolfs (1892) first published a description of a new disease on tomato where some fields in Florida showed a greater than $70 \%$ loss. Saccardo (1911) later named the fungus as Sclerotium rolfsii. Although there are several other Sclerotium producing fungi, the fungus characterized by small tan to dark-brown or black spherical sclerotia with internally differentiated rind, cortex and medulla were placed in the form genus Sclerotium (Punja and Rahe, 1992). The disease has been reported by many workers in different agro climatic zone of India. However, no systematic information and documentation is available on the prevalence of stem rot of capsicum caused by $S$. rolfsii in Karnataka. Hence, the studies were undertaken to find out the occurrence and distribution pattern of stem rot disease of capsicum in southern region of Karnataka.

\section{Materials and Methods}

Roving survey was conducted in major capsicum growing areas in Southern Karnataka (Fig.1) during the crop growing season of kharif and rabi 2018-2019. Under this survey, two taluks in Bengaluru rural, three taluks in Chikkaballapur and four taluks in Kolar districts were covered. Seven villages in Kolar taluk, four villages in Malur taluk and three villages each in Bangarpet and Srinivaspur taluks in Kolar district were assessed. In Bengaluru rural district, four villages each in Devanahalli and Doddaballapur taluks while in Chikkaballapur district, two villages in Chikkaballapur, two villages in Bagepalli and four villages in Sidlaghatta taluk were covered during the survey. In each village two to four fields were assessed depending upon the availability of the fields. The disease incidence was estimated by recording minimum 100 plants including symptomatic plants in the field. The per cent disease incidence was calculated by using the following formula,

$$
\begin{aligned}
& \text { No. of infected plants }
\end{aligned}
$$

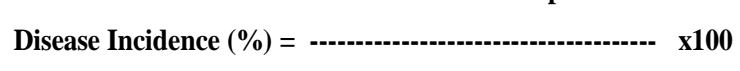

In addition to the incidence level of the disease, the details on information on stage of the crop, variety/ hybrid, cropping season, per cent disease incidence, previous crop grown, type of cultivation and chemicals used for management of the stem rot were also recorded. 


\section{Results and Discussion}

Roving survey was conducted both in kharif and rabi seasons during 2018-19 in major capsicum growing areas of Bengaluru rural, Chikkaballapur and Kolar districts to assess the distribution and incidence of stem rot of capsicum as described in material and methods Distribution of S. rolfsii incidence in Bengaluru rural, Chikkaballapur and Kolar districts are shown in Fig.1.
Disease symptoms observed during survey are shown in plate 1 . Results revealed that though the disease was prevalent in all the areas surveyed the disease was observed to be less. In Kolar district the per cent disease incidence ranged from 1.00 to 6.00 per cent, 0.00 to 05.00 per cent in Bengaluru rural district and 0.00 to 04.00 per cent in Chikkaballapur district (Table 1). Among the villages surveyed, maximum disease incidence $(6.00$ $\%$ ) was observed in Harati village in Kolar district.

Table.1 Survey for the assessment of stem rot incidence in Southern Karnataka during kharif \& rabi 2018-19

\begin{tabular}{|c|c|c|c|c|c|}
\hline SI.No. & District & Taluk & Village & Variety/Hybrid & Disease incidence (\%) \\
\hline \multirow[t]{4}{*}{1} & \multirow[t]{4}{*}{ Kolar } & Kolar & $\begin{array}{c}\text { Abbani } \\
\text { Harati } \\
\text { Nayakanahalli } \\
\text { Naganayakanahalli } \\
\text { Veeraputra } \\
\text { Chadumanahalli } \\
\text { Chakkondanahalli }\end{array}$ & $\begin{array}{l}\text { Green Machine } \\
\text { Indra } \\
\text { Yellow Bachata } \\
\text { Priyanka } \\
\text { Indra } \\
\text { Nemlite } \\
\text { Indra }\end{array}$ & $\begin{array}{l}03.00 \\
06.00 \\
01.00 \\
04.00 \\
03.00 \\
03.00 \\
02.00\end{array}$ \\
\hline & & Malur & $\begin{array}{l}\text { Malur } \\
\text { Kempasandra } \\
\text { Yashwantpura } \\
\text { Chavenahalli }\end{array}$ & $\begin{array}{c}\text { Indra } \\
\text { Indra } \\
\text { Indra } \\
\text { Green Machine }\end{array}$ & $\begin{array}{l}04.00 \\
03.00 \\
04.00 \\
02.00\end{array}$ \\
\hline & & Bangarapet & $\begin{array}{c}\text { Adampalli } \\
\text { Kuppanahalli } \\
\text { Kamandahalli }\end{array}$ & $\begin{array}{c}\text { Indra } \\
\text { Indra } \\
\text { Green Machine }\end{array}$ & $\begin{array}{l}03.00 \\
05.00 \\
02.00\end{array}$ \\
\hline & & Srinivaspur & $\begin{array}{c}\text { Nambihalli } \\
\text { Mogilahalli } \\
\text { Totliganahalli }\end{array}$ & $\begin{array}{l}\text { Indra } \\
\text { Nemlite } \\
\text { Indra }\end{array}$ & $\begin{array}{l}02.00 \\
02.00 \\
05.00\end{array}$ \\
\hline \multirow[t]{2}{*}{2} & \multirow[t]{2}{*}{ Bengaluru rural } & Devanahalli & $\begin{array}{c}\text { Koramangala } \\
\text { Doddasadarahalli } \\
\text { Singavara } \\
\text { Devanahalli }\end{array}$ & $\begin{array}{c}\text { Indra } \\
\text { Indra } \\
\text { Red Inspiration } \\
\text { Indra }\end{array}$ & $\begin{array}{l}01.00 \\
03.00 \\
02.00 \\
05.00\end{array}$ \\
\hline & & Dodballapur & $\begin{array}{c}\text { Rajaghatta } \\
\text { Mukkenahalli } \\
\text { Mukkenahalli } \\
\text { Rajaghatta }\end{array}$ & $\begin{array}{l}\text { Yellow Bachata } \\
\text { Red Inspiration } \\
\text { Yellow Bachata } \\
\text { Red Inspiration }\end{array}$ & $\begin{array}{c}0.00 \\
01.00 \\
03.00 \\
0.00\end{array}$ \\
\hline \multirow[t]{3}{*}{3} & \multirow[t]{3}{*}{ Chikkaballapur } & Chikkaballapur & $\begin{array}{l}\text { Hosahudya } \\
\text { Hosahudva }\end{array}$ & Red Inspiration & 02.00 \\
\hline & & Bagepalli & $\begin{array}{l}\text { Booragamadagu } \\
\text { Aadiganahalli }\end{array}$ & $\begin{array}{l}\text { Yellow Bachata } \\
\text { Green Massilia }\end{array}$ & $\begin{array}{l}02.00 \\
04.00\end{array}$ \\
\hline & & Sidlaghatta & $\begin{array}{l}\text { Bashettahalli } \\
\text { Bashettahalli } \\
\text { Gowdanahalli } \\
\text { Gowdanahalli }\end{array}$ & $\begin{array}{l}\text { Red inspiration } \\
\text { Nemlite } \\
\text { Yellow bachata } \\
\text { Nemlite }\end{array}$ & $\begin{array}{c}0.00 \\
01.00 \\
0.00 \\
0.00\end{array}$ \\
\hline
\end{tabular}


Fig.1 Map showing the districts surveyed for the assessment of $S$. rolfsii incidence

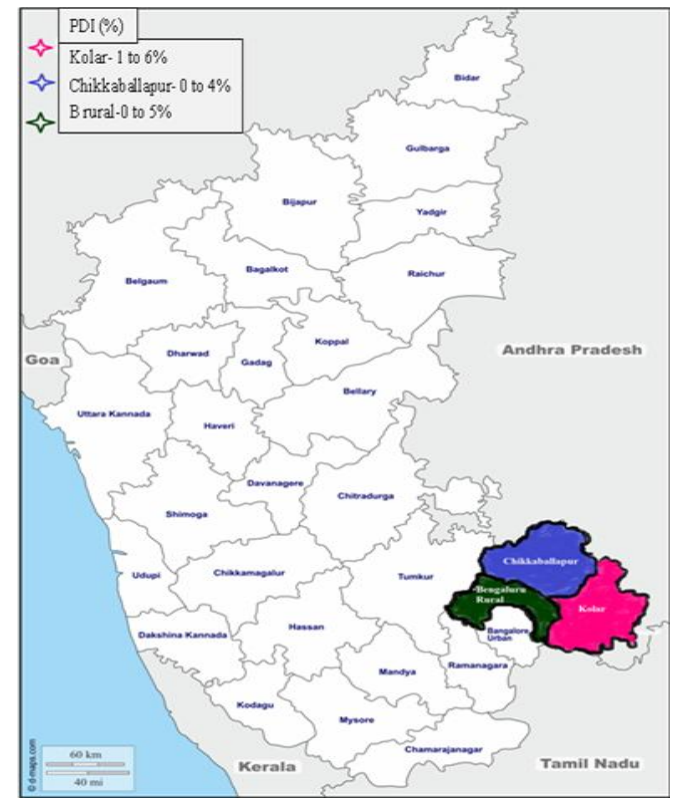

Plate.1 Disease symptoms observed during roving survey

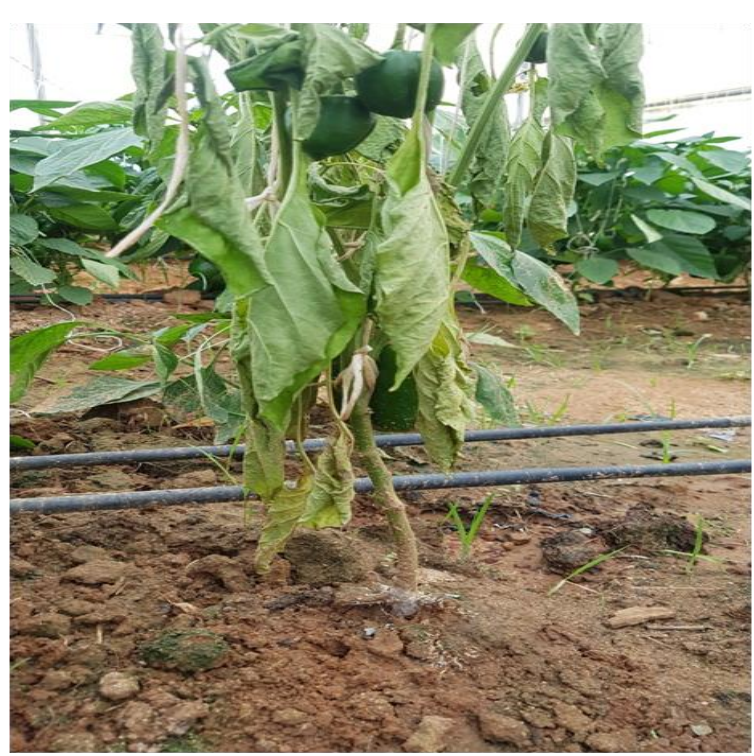

(a) White sclerotial growth at collar region

In Kolar taluk, the disease incidence ranged from 01.00 to 06.00 per cent. The highest incidence of 06.00 per cent was recorded in Harati village and least disease incidence of 01.00 per cent in Nayakanahalli village. The disease incidence in Malur taluk ranged from

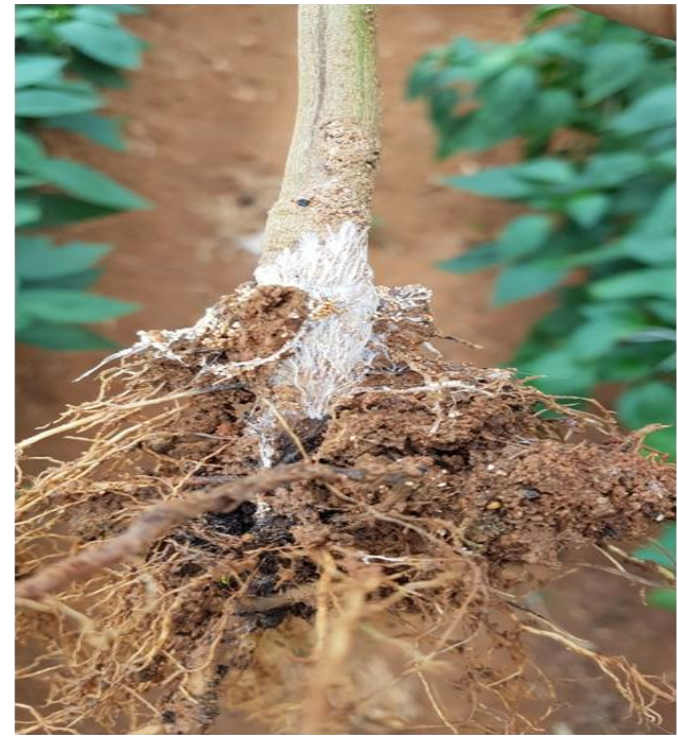

(b) Mat like mycelia growth at collar region

02.00 to 04.00 per cent, where highest disease incidence of 04.00 per cent was observed in both Malur town and Yashwantpura village followed by least disease incidence of 02.00 per cent in Chavenahalli village. The disease incidence in Bangarpet taluk ranged from 
02.00 to 05.00 per cent. Kuppanahalli village recorded the highest disease incidence of 05.00 per cent followed by Adampalli village $(3.00 \%)$ while least disease incidence $(02.00 \%)$ was noticed in Kamandahalli village. The disease incidence in Srinivaspur taluk ranged from 02.00 to 05.00 per cent where, highest disease incidence with 05.00 per cent was observed in Totliganahalli village and least disease incidence with 02.00 per cent was noticed in both Nambihalli and Mogilahalli villages.

In Bengaluru rural district, the disease incidence ranged from 0.00 to 05.00 per cent. Devanahalli town recorded 05.00 per cent disease incidence while no disease incidence $(0.00 \%)$ was noticed in Rajaghatta village. In Devanahalli taluk, the disease incidence ranged from 01.00 to 05.00 per cent, where highest disease incidence with 05.00 per cent was observed in Devanahalli town and least disease incidence with 01.00 per cent was observed in Koramangala village. The disease incidence observed in Dodballapur taluk ranged from 0.00 to 03.00 per cent where, the highest disease incidence of 03.00 per cent was observed in Mukkenahalli village and no incidence was recorded in Rajaghatta village.

In Chikkaballapur district, the disease incidence was ranging from 0.00 to 04.00 per cent. In Aadiganahalli village, 04.00 per cent disease incidence was recorded while in Hosahudya, Bashettahalli and Gowdanahalli villages, the disease incidence of 0.00 per cent was recorded. Disease incidence in Chikkaballapur taluk was ranging from 0.00 to 02.00 per cent, where the highest disease incidence of 02.00 per cent was observed in Hosahudya village and no disease incidence was observed in Hosahudya village in different field. In Bagepalli taluk, the disease incidence was ranging from 02.00 to 04.00 per cent where, the highest disease incidence of 04.00 per cent was observed in
Aadiganahalli village followed by least disease incidence of 02.00 per cent in Booragamadagu village. The disease incidence in Sidlaghatta taluk was ranging from 0.00 to 01.00 per cent where highest incidence 01.00 per cent was observed in Bashettahalli village followed by no disease incidence in Bashettahalli and Gowdanahalli villages.

The findings are in conformity with Choudhary (2013) who reported the stem rot disease incidence in the range of 5-17 per cent and recorded the highest disease incidence in black soil and rain fed areas. Singh et al., (2003) conducted the survey in kharif 19992002 in betel vine growing areas in Mahoba (Uttar Pradesh) and observed the crop affected by collar rot disease caused by $S$. rolfsii to the tune of 27 per cent and reported the disease severity ranging from 10-30 per cent. This indicates the damaging potential of $S$. rolfsii on this crop and a variety of other crops causing collar rot. In similar studies conducted by Daunde et al., (2018) collar rot disease incidence in chilli ranged from 14.01 to 18.75 per cent in the agro-climatic zones of Marathwada region of Maharashtra and the Jalna district had maximum level of disease incidence $(24.71 \%)$, followed by the districts viz., Aurangabad (21.50\%), Nanded (18.15\%), Hingoli (16.43\%), Parbhani (15.24\%) and Latur (15.22\%). Maximum mean collar rot incidence was recorded on variety Arch-930 (23.47\%) while minimum incidence on variety Sitara (11.64\%).

In conclusion the experimental results obtained in this study revealed that the stem rot of capsicum caused by Sclerotium rolfsii even though was prevalent in all the three districts of Southern Karnataka surveyed, the disease incidence was observed to be very less which might be due to the crop being cultivated in protected cultivation, where the risk of attack of pest and disease incidence is 
less. Among the three districts surveyed, Harati village in Kolar district showed maximum disease incidence of 06.00 per cent in the hybrid Indra. The per cent disease incidence ranged from 0.00 to 06.00 per cent. As observed in survey, the crop was prone to the disease at the seedling and flowering stage. However, the availability of large amount of moisture, continuous cultivation of susceptible varieties over the years, presence of inoculum in soil or entry of the pathogen might lead to severe attack of stem rot disease in these locations. The finding emphasizes on seeking new resistance sources under local conditions and encouraging of sowing resistance cultivars by following good management practices.

\section{References}

Begum, S. N., Chowdhury, B. C. and Ahamed, H. U. 1985. Screening of brinjal varieties for

resistance to $S$. rolfsii. Abst. 1st National Conf. Plant Pathology, held at Bangladesh Agricultural Research Institute, Joydebpur, Gazipur. 12 p.

Choudhary, V. 2013. Studies on biological control of collar rot of soybean caused by Sclerotium rolfsii Sacc". Rajmata Vijayaraje Scindia Krishi Vishwa
Vidyalaya, Gwalior, Pp. 45-48.

Daunde, A.T., Apet, K.T., Suryawanshi, A.P. and Khandare, V.S. 2018. Prevalence of collar rot of chilli caused by Sclerotium rolfsii Sacc. under the agroclimatic zones of Marathwada region of Maharashtra. Journal of Pharmacognosy and Phytochemistry, 7(4): 1905-1908.

Farr, D. F., Bills, G. F., Chamunis, F. P. and Rossama, A. Y. 1989. Fungi on plants and plant products in the United States. Amer. Phytopath. Soc, St. Paul, Minnesota; 78-82.

Punja, Z. K. and Rahe, J. E. 1992. Sclerotium. In: Singleton, LL, Mihail JD, Rush CM, eds. Methods for Research on Soilborne Phytopathogenic Fungi. APS Press. Pp. 166-170.

Rolfs, P. H. 1892. Tomato blight: some hints. Bulletin Fla. Agric. Experimentation Station, Pp. 18.

Saccardo, P. A. 1911. Notae Mycological. Annales Mycologici, 9: 249-257.

Singh, A. S., Mehta, H. B. and Nautiyal, C. S. 2003. Biocontrol of collar rot disease of betel vine (Piper betle L.) caused by Sclerotium rolfsii by using rhizosphere competent Pseudomonas fluorescens NBRI-N6 and NBRI-N. Current Microiol. 47(2):153-158.

\section{How to cite this article:}

Sahana, B., T. B. Manjunatha Reddy, B. Doddabasappa, B. Anjaneya Reddy, S. K. Mushrif and Amarananjundeswara, H. 2020. Survey for the Assessment of Stem Rot of Capsicum Incidence in Southern Karnataka. Int.J.Curr.Microbiol.App.Sci. 9(09): 905-910. doi: https://doi.org/10.20546/ijcmas.2020.909.112 